\title{
EFFECT OF USING L-CARNITINE, ASCORBIC ACID AND PROBIOTICS ON PRODUCTIVE PERFORMANCE, MICROBIAL LOAD AND HISTOLOGICAL OBSERVATIONS IN LOCALLY-DEVELOPED BROILERS
}

\author{
H.A. Thabet ${ }^{1}$; M.I. Shourrap ${ }^{1}$; M.A.M. Abdelaziz ${ }^{1}$ and A.F. Abdel-Salam ${ }^{2}$ \\ ${ }^{1}$ Poultry Production Department, Faculty of Agriculture, Ain Shams University, Egypt. \\ ${ }^{2}$ Regional Center for Food and Feed, Agriculture Research Center, Egypt.
}

(Received 15/1/2015, accepted 3/3/2015)

\section{SUMMARY}

\begin{abstract}
A $\mathrm{n}$ experiment was conducted to investigate effects of supplemented L-carnitine, ascorbic acid and probiotics on productive performance, carcass characteristics and some bacterial and histological aspects in locally-developed broiler strain. 252 unsexed chicks 2 weeks of age were reared up to 8 weeks of age were distributed into 7 treatments in 6 replicates of 6 birds each. The experimental groups were as follows:

T1: Control group fed basal diet.

T2: Basal diet supplemented with $500 \mathrm{mg}$ ascorbic acid / Kg diet.

T3: Basal diet supplemented with $1000 \mathrm{mg}$ ascorbic acid / Kg diet.

T4: Basal diet supplemented with $75 \mathrm{mg}$ L-carnitine / Kg diet.

T5: Basal diet supplemented with $150 \mathrm{mg}$ L-carnitine / Kg diet.

T6: Basal diet supplemented with $0.5 \mathrm{~g}$ Probiotic / Kg diet.

T7: Basal diet supplemented with $1.0 \mathrm{~g}$ Probiotic / Kg diet.

The results showed that live body weight, daily weight gain, daily feed consumption or feed conversion ratio were insignificantly different during the first 2 weeks of studied period among all groups. Birds fed T2 diet gained significantly higher weight compared with other groups at overall period. While feed conversion ratio of birds fed T4, T5, T6 and T7 were the best significantly compared with the other groups. Dressing percentage of all tested groups was increased significantly compared with control group. While birds fed T3 or T5 diets deposited significantly less abdominal fat compared with the other groups. Microbial studies showed that aerobic bacteria decreased by feeding different treatments in caecum and small intestine compared with control. Also, anaerobic (beneficial) bacteria increased in caecum and small intestine in comparison with control. As well, feeding birds on probiotics or ascorbic acid had completely eliminated Campylobacter from chicken meat. Probiotics treatment was the more effective in decreasing total bacterial count in carcass meat. Histological observation revealed that dietary treatments had a positive effect on the number and size of fasciculi and consequently their myofibers of muscles, normal liver and spleen structure was noticed, expect for some slight changes. Therefore, it is suggested that L-carnitine, ascorbic acid or probiotics, could be used safely as feed additives to improve performance without any adverse effect on body organs or gastro-intestinal tract microbial population.
\end{abstract}

Keywords: L-carnitine, ascorbic acid, probiotic, broiler, histology, microbiology

\section{INTRODUCTION}

Since decades, with the initiation and development of synthetic and semi-synthetic antibiotics and hormones which have been used as animal feed additives. However, increasing concerns regarding over use of antibiotics has prompted extensive investigation into alternatives. Hence, research workers have been experienced throughout the last five decades and being directed to the research back to natural antimicrobial products as indispensable resources. Consequently, there is considerable research interest in the possible use of natural products, like, vita- min supplements, enzymes, probiotics, medicinal plants and herbs for the development of new additives in animal feeding. Incorporation of natural feed additives as growth promoters in some countries is not exceeding more than 10 to 20 years. Use of probiotics, as animal feed additives, in our region is still new and need more emphasize to develop its applications. 


\section{Thabet et al.}

Probiotics are live microorganisms which will have beneficial effect to the host animal by improving its small intestine microbial balance through inhibiting intestinal pathogens (E. coli), and by growing and multiplying and competitively excluding undesirable bacteria (O'Keefe, 2005). In fact, mode of actions of probiotic is still unclear despite the suggestions given by Montes and Pugh (1993) 1) beneficial changes in gut flora with reductions in the population of Escherichia coli, 2) lactate production with subsequent changes in intestinal $\mathrm{pH}, 3$ ) production of antibiotic type substances, 4) production of enzymes, 5) competition for adhesion receptors in the intestine, 6) competition for nutrients, 7) reduction of toxin release and immuno-stimulation. Cavazzoni et al. (1998) evaluated performance of broiler chickens supplemented with Bacillus coagulans as probiotic and found that feeding probiotic supplements increase the growth rate of broilers. There have been many previous studies to evaluate probiotics on broiler and to give good reason for its impact on broiler growth and health status different mechanisms have been proposed. Kabir (2009) stated that probiotic effects on intestinal microflora and pathogen inhibition, intestinal histological changes, immuno-modulation, some haemato-biochemical parameters and subsequently improve growth performance of broilers. He also mentioned that probiotic improves sensory characteristics of dressed broiler meat and microbiological meat quality of broilers. However, it is mentioned that the main effect of probiotic is in the gastrointestinal tract and associated with its capacity to stimulate the immune response and to control the growth of pathogenic bacteria. Kabir (2009), Higgins et al. (2007), Huang et al. (2004) and Mountzouris et al. (2007).

The chemical name of Vitamin $\mathrm{C}$, a water-soluble vitamin, is ascorbic acid and it plays an important role in capillary fragility and joint diseases. According to the fact that some metal ions play a very important role in degrading ascorbic acid, it appears that substances that form a chelate, that is to say block metal ions, have a stabilizing effect on ascorbic acid (Cemeroglu, 2004). According to Sahin et al. (2003) $250 \mathrm{mg}$ L-ascorbic acid increased body weight gain, feed intake, feed conversion, hot and cold carcass weight in broilers.

L-carnitine as a nutritional supplement in today's commercial poultry has been considered; regarding the role of L-carnitine in fatty acid metabolism. It is expected that in addition to improve the production yield, it is important to increase the quality of meat and reduce poultry body fat gain. In this study, different levels of L-carnitine in broiler diets have been used Daskiran and Teeter (2001) and Xu et al. (2003). Reports about the effects of a diet filled with L-carnitine on performance, growth and composition of broilers are contradictory. Some studies have shown that L-carnitine supplementation improved body weight gain and decreased abdominal fat of broilers Lettner et al. (1992) and Rabie et al. (1997).

The objective of the present study was to examine effects of supplementation of L-carnitine, ascorbic acid (vitamin C) and probiotics on performance, histological observations of internal organs as well as some microbiological features in locally-developed broiler strain.

\section{MATERIALS AND METHODS}

The present study was carried out at the Poultry Nutrition Unit, Poultry Production Department, Faculty of Agriculture, Ain Shams University.

\section{Experimental diets and birds:}

Two hundred and fifty-two local developed strain 2 weeks of age with average weight of $217 \mathrm{~g}$ were distributed into seven treatments with six replicates of six chicks each in wire-floored batteries up to 8 weeks of age. The experimental diets were as follow:

T1: Control group fed basal diet

T2: basal diet supplemented with $500 \mathrm{mg}$ ascorbic acid / Kg diet.

T3: basal diet supplemented with $1000 \mathrm{mg}$ ascorbic acid / Kg diet.

T4: basal diet supplemented with $75 \mathrm{mg} \mathrm{L}$-carnitine / Kg diet.

T5: basal diet supplemented with $150 \mathrm{mg}$ L-carnitine / Kg diet.

T6: basal diet supplemented with $0.5 \mathrm{~g} \operatorname{Probax}^{\#} / \mathrm{Kg}$ diet.

T7: basal diet supplemented with $1.0 \mathrm{~g}$ Probax $^{\#} / \mathrm{Kg}$ diet.

\# Probax is a probiotic for poultry containing Lactobacillus sporogenes.

Basal diet was formulated to provide the nutrient requirements according to guideline of NRC (1994), the composition and calculated chemical analysis was listed in (Table 1). All birds were reared under 
similar environmental, managerial and hygienic conditions. Feed and water were provided ad libitum. Vaccination programs were applied according to the scheme of vaccination used in the laboratory.

Table (1): Feed ingredients and chemical composition of basal diet (control diet).

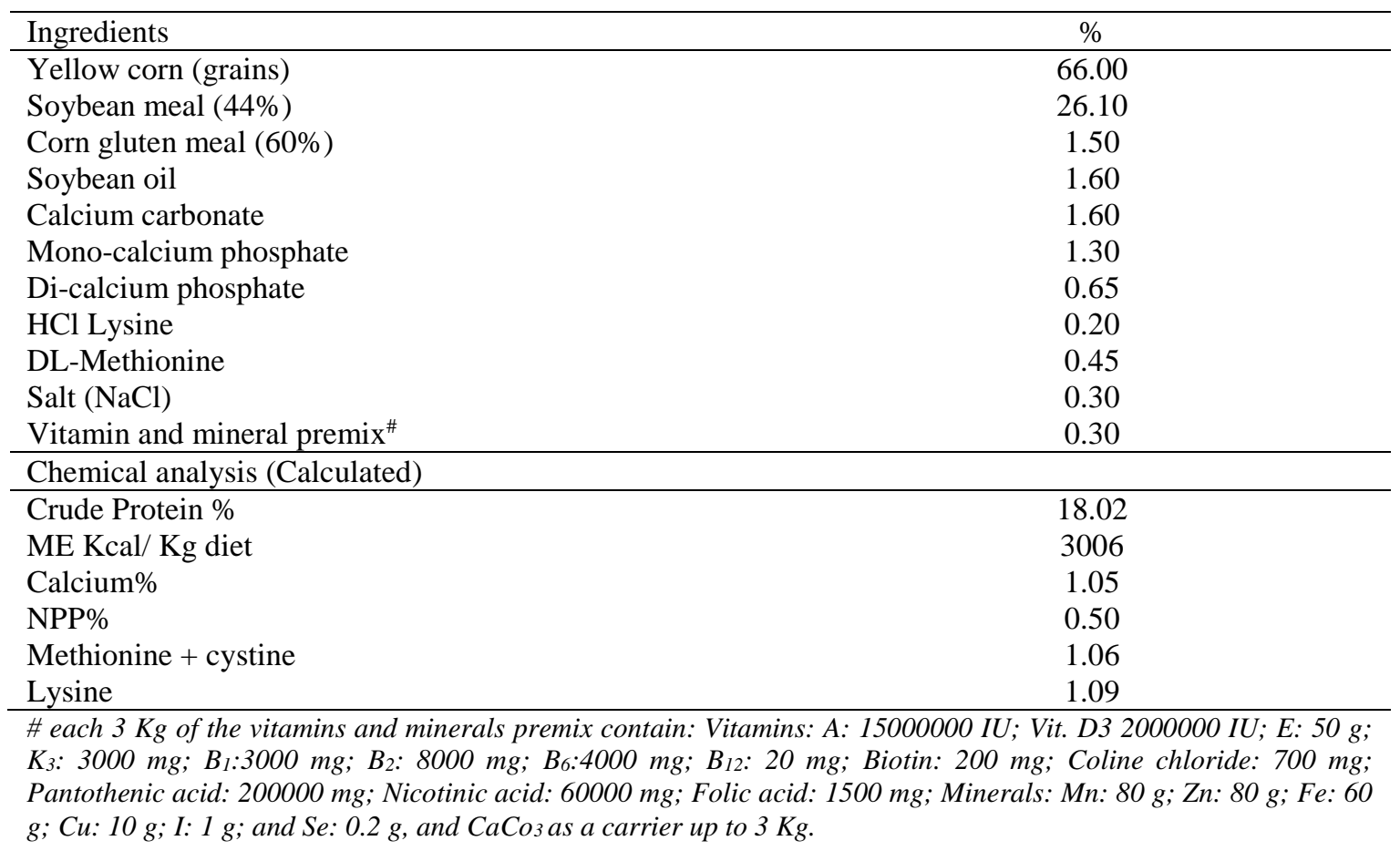

\section{Bird growth performance:}

Body weight and feed consumption were recorded weekly. Weight gain and feed conversion ratio (g feed/g gain) were calculated weekly.

\section{Bird carcass characteristics:}

At 8 weeks of age, six birds from each treatment (one from each replicate) having the average body weight of each treatment were selected and sacrificed by cervical dislocation to determine carcass characteristics.

\section{Microbiological studies:}

At 8 weeks of age, six hens of each experimental group were chosen for determination the total aerobic and anaerobic count in the small intestine and caecum. Determinations of total aerobic, mesophilic, psychrophilic, total coliform and faecal coliform counts in the meat were carried out too, while the contents of caecum, small intestine and meat were tested for Salmonella, Staph aureus, Listeria and Campylobacter infection.

Total aerobic, anaerobic, psychrophilic, mesophilic counts were carried out according to Berrang et al. (2001). Total coliform and faecal coliform counts were carried out according to Mercuri and Cox (1979). Isolation of Salmonella was carried out according to Ellis et al. (1976). The suspected colonies were subcultured on nutrient slope agar and incubated at $37 \mathrm{C}^{\circ}$ for $24 \mathrm{hr}$, biochemical tests for Salmonella identification attempts were made using the criteria described by Krieg and Hot (1984) using the following tests: growth on TSI, Urea, Indole, M.R, V.P and sugar fermentation. Serological tests were carried out according to Kauffmann (1973).

Isolation of Staph aureus was carried out according to Gouda (2002). The isolation of Staph aureus based on appears as black, convex and shiny colonies surrounded by a yellow zone on Vogel Johnson agar medium. Isolation of Campylobacter was carried out according to Oosterom et al. (1983). The isolation of Campylobacter based on appearance grey, moist, flat and spreading colonies. Isolation of Listeria was carried out according to USDA-FSIS (1989). The isolation of Listeria based on appearance dew-drop-like, dark brown or black colonies with hallo. 


\section{Thabet et al.}

\section{Tissue preparation for histological studies:}

At autopsy a representative sample $(0.5 \times 0.5 \mathrm{~cm})$ from the left major muscle pectoralis, spleen, and liver of six birds from each treatment at 8 weeks of age were carefully dissected during the slaughtered time and immediately fixed in adequate volume of $10 \%$ formalin solution. The paraffin technique has been used according to (Junqueira et al., 1971; Al-Hussaini and Demian, 1974; Abd El-Hamid, 1981). Thin sections (4-5 micron) were cut, and mounted on glass slides (two sections/sample/slide), then stained with the ordinary hematoxyline and eosin stain procedures.

The histological technique of muscles and lymphoid organs were conducted in the Pathology Laboratory, National Cancer Institute, Cairo Univ., Egypt. The histological structures of pectoral muscles, liver and spleen where observed using light microscope (Labomed, LX 400. Labo, America, Inc. USA) endorsed with a digital camera under low $\times 10$ and high $\times 40$ magnification. Photography shots from the selected specimens were prepared for better illustration of the results.

\section{Statistical Analysis:}

Data were subjected to one-way ANOVA analysis of variance General Linear Model (GLM) procedure of SAS software SAS (1998) user's guide according to the following model:

Yij $=\mu+\mathrm{Ti}+\mathrm{eij}$

Where; Yij = the obtained experimental observation, $\mu=$ overall mean, $\mathrm{T} \mathrm{i}=$ dietary treatment, e $\mathrm{ij}=$ experimental error. Individual effects of dietary treatments were compared using Duncan (1955) multiple range tests at $\alpha$ level equal to 0.05 or 0.01 .

\section{RESULTS AND DISCUSSION}

\section{Productive performance:}

Data presented in (Table 2) showed the effect of L-carnitine, ascorbic acid and probiotic on productive performance traits. Birds fed basal diet supplemented with experimental treatment didn't differ with control group during first two weeks of experimental period for live body weight, daily weight gain, and daily feed consumption and feed conversion ratio.

For daily weight gain (BWG), birds fed basal diet supplemented with $1 \mathrm{~g} / \mathrm{Kg}$ probiotic (T7) gained more weight compared with control group where recorded $29.49 \mathrm{~g} /$ day compared with $27.27 \mathrm{~g} /$ day for control group with significant differences $(\mathrm{P} \leq 0.01)$.

These results were in harmony with those obtained by Kaoud (2010) who reported significant increase in BWG of broilers fed probiotic mixture (containing Lactobacillus acidophilus, Lactobacillus sporogenes and Saccharomyces cerevisiae) at $0.5 \mathrm{~g} / \mathrm{Kg}$ feed at 6 week of age. Similar reactions for broiler chickens fed with probiotic were also reported by Panda et al. (2006) and Mountzouris et al. (2007). The improvement in body weight gain in present study could be ascribed to improvement in digestion and absorption of nutrients in the digestive tract due to presence of amylase derived from the Lactobacilli and promotion of health status of broilers (Bansal et al., 2011).

In contrast, probiotics supplementation did not improve the body weight gain in broilers (Midilli et al. (2008). On the other hand, birds fed diets supplemented with ascorbic acid (1000 mg/ Kg) gained weight more than control but without significant manner, these results were in agreement with those obtained by Sosnowka-Czajka, et al. (2005). In contrast to our results, El-Shafei et al. (2013) did not obtain any improved weight gain in the supplemental groups of ascorbic acid, and Konca et al. (2009) also stated that growth performance of broiler chickens was not influenced by ascorbic acid supplementation. Lcarnitine supplementations $(150 \mathrm{mg} / \mathrm{Kg})$ didn't gained significant weight compared with control (27.65 vs. 27.27), these finding were in concert with those of Rabie and Szilagyi (1998) and Buyse et al. (2001) who observed a positive effect of L-carnitine on the body weight of chickens on the end of fattening period but the differences were not significant $(P<0.05)$

Other authors who studied the effect of L-carnitine on broiler performance found no effect on body weight (Lien and Horng, 2001; Xu et al., 2003; Cevik and Ceylan, 2005). Probiotic supplementations didn't affect daily feed consumption compared with control, birds fed basal diet supplemented with 0.5 or $1 \mathrm{~g} / \mathrm{Kg}$ probiotic consumed feed (64.70 or 70.62) similar to control group (68.35) without any significant differences. These data were similar with those obtained by Chumpawadee et al. (2008) and Midilli et al. 
(2008). On the contrary the finding of Balevi et al. (2000) indicated that supplementation with probiotic at a level of $0.5 \mathrm{~g} / \mathrm{Kg}$ diet improved feed intake.

Ascorbic acid supplementations didn't have an effect on daily feed consumption; the results were $68.35,68.80$, and $69.62 \mathrm{~g}$ for control, 500 and $1000 \mathrm{mg} / \mathrm{Kg}$ respectively. These results were in agreement with those obtained by Sabah-Elkheir et al. (2008); Onu (2009). On the other hand, Villar-Patiño et al. (2002) reported that ascorbic acid supplemented diets resulted in lower feed consumption. L-carnitine supplemented diets caused lower daily feed consumption with insignificant differences. Birds fed Lcarnitine consumed 65.14 and 65.07 for 75 and $150 \mathrm{mg} / \mathrm{Kg}$, respectively compared with 68.35 for control group. These results agreed with Leibetseder (1995) and Buyse et al. (2001). But it was in contrast with those of Geng et al. (2007) and Hrnčár et al. (2015).

Table (2): Effect of different dietary treatments on productive performance.

\begin{tabular}{|c|c|c|c|c|c|c|c|c|c|}
\hline \multirow{2}{*}{ Items } & \multicolumn{9}{|c|}{ Dietary Treatments } \\
\hline & $\mathrm{T} 1$ & $\mathrm{~T} 2$ & T3 & $\mathrm{T} 4$ & T5 & T6 & $\mathrm{T} 7$ & Sig & SEM $^{\#}$ \\
\hline \multicolumn{10}{|c|}{ Live body weight (g) } \\
\hline 4 weeks & 547.17 & 555.17 & 555.31 & 547.33 & 551.75 & 539.42 & 560.89 & NS & 49.12 \\
\hline 6 weeks & $952.47^{\mathrm{ab}}$ & $913.31^{\mathrm{b}}$ & $955.25^{\mathrm{ab}}$ & $920.78^{b}$ & $967.44^{\mathrm{a}}$ & $961.36^{\mathrm{ab}}$ & $965.42^{\mathrm{ab}}$ & $*$ & 75.25 \\
\hline 8 weeks & $1362.36^{\mathrm{b}}$ & $1335.47^{\mathrm{b}}$ & $1361.81^{\mathrm{ab}}$ & $1328.81^{\mathrm{b}}$ & $1387.50^{\mathrm{ab}}$ & $1374.44^{\mathrm{ab}}$ & $1455.67^{\mathrm{a}}$ & $* *$ & 93.21 \\
\hline \multicolumn{10}{|c|}{ Daily weight gain (g) } \\
\hline 2-4 weeks & 23.59 & 24.18 & 24.11 & 23.58 & 23.84 & 23.14 & 24.57 & NS & 0.56 \\
\hline 4-6 weeks & $28.58^{\mathrm{ab}}$ & $25.58^{\mathrm{b}}$ & $28.57^{\mathrm{ab}}$ & $26.67^{\mathrm{b}}$ & $29.69^{\mathrm{a}}$ & $30.14^{\mathrm{a}}$ & $28.89^{\mathrm{ab}}$ & $*$ & 0.95 \\
\hline 6-8 weeks & $29.28^{\mathrm{b}}$ & $30.15^{\mathrm{b}}$ & $29.04^{\mathrm{a}}$ & $29.14^{\mathrm{b}}$ & $30.03^{b}$ & $29.49^{b}$ & $35.02^{\mathrm{a}}$ & $*$ & 0.60 \\
\hline 2-8 weeks & $27.27^{\mathrm{b}}$ & $26.64^{\mathrm{b}}$ & $27.24^{\mathrm{b}}$ & $26.47^{\mathrm{b}}$ & $27.65^{\mathrm{b}}$ & $27.54^{\mathrm{b}}$ & $29.49^{\mathrm{a}}$ & $* *$ & 0.89 \\
\hline \multicolumn{10}{|c|}{ Daily feed consumption $(\mathrm{g})$} \\
\hline 2-4 weeks & 50.67 & 51.06 & 49.01 & 48.48 & 50.23 & 49.30 & 47.79 & NS & 5.26 \\
\hline 4-6 weeks & 69.65 & 71.40 & 73.86 & 68.66 & 69.29 & 66.77 & 73.99 & NS & 8.36 \\
\hline 6-8 weeks & $84.64^{\mathrm{a}}$ & $83.92^{\mathrm{a}}$ & $86.00^{\mathrm{a}}$ & $78.27^{\mathrm{ab}}$ & $75.68^{\mathrm{b}}$ & $78.03^{\mathrm{b}}$ & $90.09^{\mathrm{a}}$ & $*$ & 12.87 \\
\hline 2-8 weeks & $68.35^{\mathrm{ab}}$ & $68.80^{\mathrm{ab}}$ & $69.62^{\mathrm{ab}}$ & $65.14^{\mathrm{b}}$ & $65.07^{\mathrm{b}}$ & $64.70^{\mathrm{b}}$ & $70.62^{\mathrm{a}}$ & $*$ & 4.14 \\
\hline \multicolumn{10}{|c|}{ Feed conversion ratio (g feed/g gain) } \\
\hline $2-4$ weeks & 2.14 & 2.11 & 2.03 & 2.06 & 2.10 & 2.13 & 1.95 & NS & 0.24 \\
\hline 4-6 weeks & $2.44^{\mathrm{ab}}$ & $2.79^{a}$ & $2.58^{\mathrm{a}}$ & $2.58^{\mathrm{a}}$ & $2.33^{\mathrm{b}}$ & $2.22^{\mathrm{b}}$ & $2.57^{\mathrm{a}}$ & $*$ & 0.33 \\
\hline 6-8 weeks & $2.87^{\mathrm{a}}$ & $2.78^{a}$ & $2.96^{\mathrm{a}}$ & $2.68^{\mathrm{ab}}$ & $2.52^{\mathrm{b}}$ & $2.64^{\mathrm{ab}}$ & $2.69^{\mathrm{ab}}$ & $*$ & 0.55 \\
\hline 2-8 weeks & $2.51^{\mathrm{a}}$ & $2.59^{\mathrm{a}}$ & $2.56^{\mathrm{a}}$ & $2.46^{\mathrm{ab}}$ & $2.35^{\mathrm{b}}$ & $2.34^{\mathrm{b}}$ & $2.39^{\mathrm{b}}$ & $*$ & 0.74 \\
\hline
\end{tabular}

T1: Basal diet, T2: Basal diet + Ascorbic acid $500 \mathrm{mg} / \mathrm{Kg}$, T3: Basal diet + Ascorbic acid $1000 \mathrm{mg} / \mathrm{Kg}$, T4: Basal diet + L-Carnitine $75 \mathrm{mg} / \mathrm{Kg}$, T5: Basal diet + L-Carnitine $150 \mathrm{mg} / \mathrm{Kg}$, T6: Basal diet + Probax $0.5 \mathrm{~g} / \mathrm{Kg}$, T7: Basal diet + Probax $1.0 \mathrm{~g} / \mathrm{Kg}$. a, b Means within the same row with different superscripts are significantly different. Sig. = Significance ** $(P \leq 0.01), *(P \leq 0.05) . N S=$ Non Significant, \# Pooled SEM.

Regarding to feed conversion ratio (FCR), birds fed basal diet supplemented with $0.5 \mathrm{~g} / \mathrm{Kg}$ probiotics were the best with significant differences with control and ascorbic acid treatments but with insignificant differences with L-carnitine and $1 \mathrm{~g} / \mathrm{Kg}$ probiotic treatments. Probiotic supplementation improves FCR due to its effect on daily weight gain and/ or daily feed consumption. These finding were in agreement with those obtained by Kaoud (2010) and Swain et al. (2012). The improvement in FCR due to the beneficial effects of probiotics represented in toxin neutralization, prevention of development and multiplication of specific bacteria, change in microbial metabolism and immunity stimulation (Fuller, 1989), in addition to the prevalence of their population against the adverse pathogens of digestive system (Bilgili and Moran, 1995).

Ascorbic acid supplementations didn't affect FCR compared with control; these were in harmony with Sosnowka-Czajka, et al. (2005) and Ogunwole et al. (2013) who found any improvement in feed conversion in broiler chickens due to ascorbic acid supplementation. However, these results contradicted with Blaha et al. (2000) and Onu, (2009) who found that ascorbic acid supplementation significantly improved FCR. Birds fed basal diet supplemented with L-carnitine $150 \mathrm{mg} / \mathrm{Kg}$ recorded better FCR than control (2.35 vs. 2.51) with significant differences. It was in harmony with Xu et al. (2003) and Santine et al. (2001). But our results are not supported by the studies of Buyse et al. (2001) and Rezaei et al. (2007), according to these authors L-carnitine supplemented to chickens had no effect on FCR.

\section{Carcass characteristics:}

Data presented in Table (3) showed effects of experimental treatments on some carcass characteristics. There was an improvement in dressing percentage for all experimental groups when compared to control 
group. Birds fed probiotic at level $1 \mathrm{~g} / \mathrm{Kg}$ was significantly better than control (68.13 vs. 64.27). Also, liver \% was increased due to probiotic supplementation. These results were in harmony with those of Kaoud (2010) and Swain et al. (2012) who found that the eviscerated yield and weight of cut up parts (breast yield) were increased $(\mathrm{P}<0.05)$ in chicks fed diet supplemented with probiotic-yeast mixture $1.0 \mathrm{~g} /$ $\mathrm{Kg}$ feed. The improvement in carcass yield may be due to better gut health and reduced pathogen load in the gastro-intestinal tract resulting in decreased post harvest loss and higher carcass yield (Swain et al., 2012).

Table (3): Effect of different dietary treatments on carcass traits, at 8 weeks of age.

\begin{tabular}{|c|c|c|c|c|c|c|c|c|c|}
\hline \multirow{2}{*}{ Items } & \multicolumn{9}{|c|}{ Dietary Treatments } \\
\hline & $\mathrm{T} 1$ & $\mathrm{~T} 2$ & T3 & $\mathrm{T} 4$ & T5 & T6 & T7 & $\mathrm{Sig}$ & SEM $^{\#}$ \\
\hline$\overline{\text { Dressing \% }}$ & $64.27^{\mathrm{b}}$ & $66.46^{\mathrm{ab}}$ & $68.07^{\mathrm{a}}$ & $67.69^{a}$ & $67.54^{\mathrm{a}}$ & $66.37^{a b}$ & $68.13^{\mathrm{a}}$ & $* *$ & 5.98 \\
\hline Liver $\%$ & $1.66^{\mathrm{b}}$ & $1.77^{\mathrm{a}}$ & $1.40^{\mathrm{b}}$ & $1.75^{\mathrm{a}}$ & $1.81^{\mathrm{a}}$ & $1.87^{\mathrm{a}}$ & $1.79^{\mathrm{a}}$ & $* *$ & 0.08 \\
\hline Gizzard \% & 1.47 & 1.51 & 1.70 & 1.60 & 1.58 & 1.78 & 1.50 & NS & 0.06 \\
\hline Heart $\%$ & 0.47 & 0.44 & 0.47 & 0.43 & 0.59 & 0.45 & 0.41 & NS & 0.01 \\
\hline Spleen $\%$ & 0.19 & 0.19 & 0.16 & 0.17 & 0.18 & 0.19 & 0.18 & NS & 0.01 \\
\hline Bursa $\%$ & $0.30^{\mathrm{a}}$ & $0.35^{\mathrm{a}}$ & $0.19^{\mathrm{b}}$ & $0.35^{\mathrm{a}}$ & $0.35^{\mathrm{a}}$ & $0.38^{\mathrm{a}}$ & $0.18^{\mathrm{b}}$ & $*$ & 0.01 \\
\hline Thymus $\%$ & 0.29 & 0.29 & 0.27 & 0.32 & 0.39 & 0.33 & 0.28 & NS & 0.01 \\
\hline Gizz. Fat \% & $1.18^{\mathrm{a}}$ & $0.98^{b}$ & $0.91^{\mathrm{b}}$ & $1.11^{\mathrm{a}}$ & $0.80^{\mathrm{b}}$ & $0.85^{\mathrm{b}}$ & $0.71^{\mathrm{b}}$ & $*$ & 0.01 \\
\hline Abd. Fat \% & 1. $94^{\mathrm{a}}$ & $1.87^{\mathrm{a}}$ & $1.20^{\mathrm{b}}$ & $1.68^{\mathrm{ab}}$ & $1.56^{\mathrm{b}}$ & $1.97^{\mathrm{a}}$ & $1.83^{\mathrm{ab}}$ & $* *$ & 0.03 \\
\hline Giblets \% & $3.60^{\mathrm{b}}$ & $3.72^{b}$ & $3.56^{\mathrm{b}}$ & $3.78^{b}$ & $3.98^{\mathrm{a}}$ & $4.10^{\mathrm{a}}$ & $3.70^{\mathrm{b}}$ & $* *$ & 0.09 \\
\hline
\end{tabular}

T1: Basal diet, T2: Basal diet + Ascorbic acid $500 \mathrm{mg} / \mathrm{Kg}$, T3: Basal diet + Ascorbic acid $1000 \mathrm{mg} / \mathrm{Kg}$, T4: Basal diet + L-Carnitine $75 \mathrm{mg} / \mathrm{Kg}$, T5: Basal diet + L-Carnitine $150 \mathrm{mg} / \mathrm{Kg}$, T6: Basal diet + Probax 0.5 g/ Kg, T7: Basal diet + Probax $1.0 \mathrm{~g} / \mathrm{Kg}$. .a,b Means within the same row with different superscripts are significantly different. Sig. = Significance ** $(P \leq 0.01)$, * $(P \leq 0.05) . N S=$ Non Significant, \# Pooled SEM.

Birds fed ascorbic acid at level $1000 \mathrm{mg} / \mathrm{Kg}$ were significantly better than control (68.07 vs. 64.27). Also, abdominal fat $\%$ was decreased and liver $\%$ increased due to ascorbic acid supplementation. These findings were in agreement with Mbajiorgu et al. (2007) and Sahin et al. (2003) who recorded an increased liver, heart, spleen and empty gizzard weight in birds on dietary ascorbic acid supplementation. Ogunwole et al. (2013) found no significant ( $\mathrm{P}>0.05$ ) differences in obtained bled, defeathered and carcass weights of broiler birds. Birds fed L-carnitine 75 and $150 \mathrm{mg} / \mathrm{Kg}$ recorded 67.69 and $67.54 \%$ dressing, respectively compared with $64.27 \%$ for control. Similar results were obtained by Hrnčár et al. (2015) who found higher carcass yield of males and females that received L-carnitine compared to the control group. Also, gizzard fat was decreased due to L-carnitine supplementation, in agreement with Wang et al. (2003). These authors recorded statistically significant decrease of fat content in the experimental broiler chickens supplemented with L-carnitine.

\section{Bacterial Count:}

Results showed in Table (4) indicated that aerobic bacteria in caecum and small intestine, was decreased by feeding any of dietary treatments, compared with control diet, till reached its lower count by feeding probiotic (T7), decreased from $8 \times 10^{11}$ and $6 \times 10^{12}$ to $6 \times 10^{3}$ and $7 \times 10^{4} \mathrm{cfu} / \mathrm{g}$ in caecum and small intestine, respectively.

Table (4): Effect of different dietary treatments on bacterial counts (cfu/ g).

\begin{tabular}{llccccccc}
\hline \multirow{2}{*}{ Items } & & \multicolumn{7}{c}{ Dietary Treatments } \\
\cline { 3 - 8 } & & $\mathrm{T} 1$ & $\mathrm{~T} 2$ & $\mathrm{~T} 3$ & $\mathrm{~T} 4$ & $\mathrm{~T} 5$ & $\mathrm{~T} 6$ & $\mathrm{~T} 7$ \\
\hline \multirow{2}{*}{ Caecum } & Aerobic & $8 \times 10^{11}$ & $6 \times 10^{6}$ & $10 \times 10^{5}$ & $6 \times 10^{8}$ & $15 \times 10^{6}$ & $9 \times 10^{4}$ & $6 \times 10^{3}$ \\
Small & Anaerobic & $9 \times 10^{8}$ & $8 \times 10^{12}$ & $30 \times 10^{12}$ & $3 \times 10^{11}$ & $15 \times 10^{13}$ & $6 \times 10^{14}$ & $6 \times 10^{14}$ \\
Intestine & Aerobic & $6 \times 10^{12}$ & $16 \times 10^{8}$ & $6 \times 10^{8}$ & $22 \times 10^{8}$ & $4 \times 10^{5}$ & $7 \times 10^{4}$ & $7 \times 10^{4}$ \\
& Anaerobic & $14 \times 10^{7}$ & $9 \times 10^{8}$ & $11 \times 10^{9}$ & $5 \times 10^{8}$ & $12 \times 10^{13}$ & $25 \times 10^{13}$ & $25 \times 10^{13}$ \\
& Total count & $20 \times 10^{4}$ & $12 \times 10^{2}$ & $3 \times 10^{2}$ & $9 \times 10^{2}$ & $5 \times 10^{2}$ & $9 \times 10$ & $6 \times 10$ \\
Carcass & Mesophilic & $9 \times 10^{4}$ & $25 \times 10$ & $2 \times 10^{2}$ & $6 \times 10^{3}$ & $12 \times 10$ & $8 \times 10$ & $3 \times 10$ \\
Meat & Psychrophilic & 0 & 0 & 0 & 0 & 0 & 0 & 0 \\
& Total coliform & 0 & 0 & 0 & 0 & 0 & 0 & 0 \\
& Faecal coliform & 0 & 0 & 0 & 0 & 0 & 0 & 0 \\
\hline
\end{tabular}

T1: Basal diet, T2: Basal diet + Ascorbic acid $500 \mathrm{mg} / \mathrm{Kg}$, T3: Basal diet + Ascorbic acid $1000 \mathrm{mg} / \mathrm{Kg}$, T4: Basal diet + L-Carnitine $75 \mathrm{mg} / \mathrm{Kg}$, T5: Basal diet + L-Carnitine $150 \mathrm{mg} / \mathrm{Kg}$, T6: Basal diet + Probax $0.5 \mathrm{~g} / \mathrm{Kg}$, T7: Basal diet + Probax $1.0 \mathrm{~g} / \mathrm{Kg}$. 


\section{Thabet et al.}

On contrary, anaerobic (beneficial) bacteria in caecum and small intestine, was increased gradually until reached its higher count by feeding probiotic (T6 or T7) in comparison with control, decreased from $9 \times 10^{8}$ and $14 \times 10^{7}$ to $6 \times 10^{14}$ and $25 \times 10^{13} \mathrm{cfu} / \mathrm{g}$ in caecum and small intestine, respectively. Accordingly, probiotic treatments (T6 or T7) presents better efficacy in regard to both aerobic and anaerobic bacteria. These results assure the fact that are some probiotics provide binding sites for pathogenic bacteria that are then flushed out of the digestive tract with the faeces while others promote the growth of beneficial bacteria by acting as a food source (McCann et al., 2006).

Also data presented in Table (4) showed that carcass meat samples were negative to psychrophilic, total coliform and faecal coliform. Different dietary treatments (ascorbic acid, L-carnitine or probiotic) decreased total bacterial and mesophilic bacteria count when compared to control group. Probiotic treatments were more effective in controlling total bacterial and mesophilic bacteria of carcass meat, decreased from $20 \times 10^{4}$ and $9 \times 10^{4}$ to $6 \times 10$ and $3 \times 10 \mathrm{cfu} / \mathrm{g}$, respectively. Findings of bacteria count were in agreement with several authors (Ceylan et al., 2003; Mountzouris et al., 2007; Corduk et al., 2008). Additionally, results provided in Table (5) revealed that caecum, small intestine and meat samples were free of Salmonella and Listeria but contained Staph aureus. While dietary application of probiotics or ascorbic acid (T2, T3, T6 or T7) completely eliminated Campylobacter from chicken meat.

Table (5): Effect of different dietary treatments on incidence of pathogenic bacteria.

\begin{tabular}{|c|c|c|c|c|c|c|c|c|}
\hline \multirow{2}{*}{ Items } & & \multicolumn{7}{|c|}{ Dietary Treatments } \\
\hline & & $\mathrm{T} 1$ & $\mathrm{~T} 2$ & T3 & $\mathrm{T} 4$ & T5 & T6 & T7 \\
\hline \multirow{4}{*}{ Caecum } & Salmonella & - & - & - & - & - & - & - \\
\hline & Staph aureus & + & 0 & 0 & + & + & 0 & 0 \\
\hline & Listeria & - & - & - & - & - & - & - \\
\hline & Campylobacter & + & 0 & - & - & + & - & - \\
\hline \multirow{4}{*}{$\begin{array}{l}\text { Small } \\
\text { Intestine }\end{array}$} & Salmonella & - & - & - & - & - & - & - \\
\hline & Staph aureus & + & 0 & 0 & + & + & 0 & 0 \\
\hline & Listeria & - & - & - & - & - & - & - \\
\hline & Campylobacter & + & 0 & 0 & + & + & - & - \\
\hline \multirow{4}{*}{$\begin{array}{l}\text { Carcass } \\
\text { Meat }\end{array}$} & Salmonella & - & - & - & - & - & - & - \\
\hline & Staph aureus & + & 0 & 0 & + & + & 0 & 0 \\
\hline & Listeria & - & - & - & - & - & - & - \\
\hline & Campylobacter & + & - & - & + & + & - & - \\
\hline
\end{tabular}

T1: Basal diet, T2: Basal diet + Ascorbic acid $500 \mathrm{mg} / \mathrm{Kg}$, T3: Basal diet + Ascorbic acid $1000 \mathrm{mg} / \mathrm{Kg}$, T4: Basal diet + L-Carnitine $75 \mathrm{mg} / \mathrm{Kg}$, T5: Basal diet + L-Carnitine $150 \mathrm{mg} / \mathrm{Kg}$, T6: Basal diet + Probax 0.5 g/ Kg, T7: Basal diet + Probax $1.0 \mathrm{~g} / \mathrm{Kg}$.

\section{Muscles histological examinations:}

The major components of muscles are muscle fibres which termed myofibers (m). Muscle fibers are highly specialized cells acting as the structural units of skeletal muscle tissue (Hedrick et al., 1994). It is clear that within each muscle fasciculi many individual muscle fibers are spaced from each other by fine connective tissue septa called endomysium (e). And fasciculi are separated from each other by connective septa called perimysium (p). It is well known that muscle fibers number, size, and fiber-type composition are closely related to each other (Ryu et al., 2004).

The performance of muscle in adult animal largely depends on muscle fiber number and type and therefore on fibre size. The muscle weight is a function of total number of myofibres, myofibre crosssection area, and length (Tumova and Teimouri, 2009). The microscopic structure of major pectoralis muscles from different treatment groups (Figure, 1) showed some changes related to our applied treatment. The myofiber size and number are increased by feeding birds both levels of ascorbic acid (T2, T3) or L-carnitine (T4, T5) or Probiotic (T6, T7). The endomysium layer was fine and delicate in bird feed both levels of L-carnitine and probiotics compared with the sections from bird of other treatments which means presence of many muscles fibers with each fasciculi. However, the perimysium was thick in birds feed both levels of ascorbic acid and L-carnitine compared with the other sections.

Regardless of different treatments levels the histological observations indicate superiority probiotic, L-carnitine and ascorbic acid, respectively, on characteristics of muscle structure. These findings reinforce the results of live body weight and dressing percent of birds obtained at 8 weeks of age, see (Tables, 2 and 3). It could be concluded that the applied treatments had a positive effect on the number 


\section{Thabet et al.}

and size of fasciculi and consequently their myofibers content which may explain and support the enhanced growth of performance of the treatment groups.

\section{Liver histological examinations:}

Histological examination of liver sections from different treatment groups (Figure, 2) showed moderate changes. It is clear that the liver parenchyma of the control (T1) showed normal hepatocytic structure with few necrotic areas and blood sinuses. The same was also observed in (T2) liver section; however, there is moderate hypertrophy of liver cells in (T3) section accompanied with dilation of portal vein. This is the case in (T4) which may reveal hyperactivity of hepatic tissue. Moreover, liver sections of (T5, T6 and T7) groups showed dilated portal vein (T5 and T6) engorged with erythrocytes.

There are also necrotic areas and some infiltrated fluids near the portal vein especially in T6 and T7 treatment groups. In general, liver sections of all treatment groups were normal in their structure expect for some slight changes related to the hyper activity of liver cells due to the role of liver in metabolic activities.

\section{Spleen histological examinations:}

Spleen sections of different treatments are illustrated in (Figure, 3). In (T1) group, spleen section showed the normal structure of the splenic tissues, where a large white pulp (WP) area and dark-stained red pulp area (RP) could be seen. This is the same in all sections; expect the proportion of the two areas and the number and size of lymphocytes in all tissues.

It is clear that the number of large (LL) and small (SL) lymphocytes was greater in (T2, T3 and T6) were greater than the other treatments. Moreover, (T5 and T7) sections showed an obvious increase in the large lymphocytes than the small ones. It appears from these sections that the applied treatments had a desirable and beneficial effect on spleen tissues which indicate their importance as feed additives.

\section{CONCLUSION}

After reviewing results of the present study, it might be suggested that additives used (L-carnitine, ascorbic acid or probiotics), could be applied to broiler (locally-developed) diets in order to improve bird's productive performance without any adverse effect on internal body organs or microbial population of gastro-intestinal tract.

\section{ACKNOWLEDGMENTS}

The support given by Prof. F. Abdelazeem for financing this research project was acknowledged. We also thank Prof. I. El-Wardani for his effort given during interpretation of histological examinations.

\section{REFERENCES}

Abd El-Hamid, Z. (1981). Histology: Part I Dar El Shaab for Press, Cairo, Egypt, Pages I-XI, 113-118.

Al-Hussaini, A.H. and E.S. Demian (1974). Practical Animal Biology. Vol. 1. The Toad. 3rd, ed. Dar ElMaarf, Cairo, Egypt. Pages 280-290.

AOAC (1995). Association of Official Analytical Chemists. Official methods of analysis $16^{\text {th }}$ ed. Volume 2, Washington D.C., USA.

Balevi, T.; U.S. Ucan; B. Coskun; V. Kurtoglu and S. Cetingul (2000). Effect of a commercial probiotic in the diet on performance and humoral immune system in layers. Hayvancilik Arastirma Dergisi., 10: 25-30.

Bansal, G.R.; V.P. Singh and N. Sachan (2011). Effect of probiotic supplementation on the performance of broilers. Asia. J. Anim. Sci., 5: 277-284. 


\section{Thabet et al.}

Berrang, M.E,; S.R. Ladely and R.J. Buhr (2001). Presence and level of campylobacter, coliforms, Escherichia coli and total aerobic bacteria recorded from broiler parts with and without skin. Food Prot., 64(2): 184-188.

Bilgili, S.F. and E.T. Moran (1995). Influence of whey and probiotic supplemented withdrawal feed on the retention of salmonella incubated into marked age broiler. Poult. Sci., 69: 1670-1674.

Blaha, J.; J. Draslarova and K. Kroesna (2000). The effect of vitamin and electrolyte supplement on broiler performance under stress. Agric. Trop. Subtrop., 33: 52-58.

Buyse, J.; G.P. Janssens and J. Decuypere (2001). The effects of dietary L-carnitine supplementation on the performance, organ weights and circulating hormone and metabolite concentrations of broiler chickens reared under a normal or low temperature schedule. Br. Poult. Sci., 42: 230-241.

Cavazzoni, V.; A. Adami and C. Castroville (1998). Performance of broiler chickens supplemented with Bacillus coagulans as probiotic. Brit. Poult. Sci., 39 (4): 526-529.

Cemeroglu, B. (2004). Meyve ve Sesbze İşleme Teknolojisi (in Turkish). 1. Cilt, 2. Baskı, Gıda Tekn Dern Yayınl, 35: 55-60.

Cevik, A.F. and N. Ceylan (2005). Effects of dietary L-carnitine supplementation on performance and carcass traits of broiler chickens. 3rd Ulusal Hayvan Besleme Kongresi, Adana, pp.391-396.

Ceylan, N., I. Ciftci, F. Ilhan and A. Sogut, (2003). Effects of enzyme, growth promoter, probiotic and organic acid supplementation to broiler diets on performance and gut microflora. Univ. of Ankara J. Agri. Sci., 9 (3), 320-326.

Chumpawadee, S.; O. Chinrasri; T. Somchan; S. Ngamluan and S. Soychunta (2008). Effect of dietary inclusion of cassava yeast as probiotics source on growth performance, small intestine (ileum) morphology and carcass characteristic in broilers. Intl. J. Poult. Sci., 7: 246-250.

Corduk, M., N. Ceylan; N. Dede and O.Y. Tel (2008). Effects of novel feed additives on performance, carcass traits and E. coli, aerobic bacteria and yeast counts in broilers. Arch.Geflügelk., 72 (2): 61-67.

Daskiran, M. and R.G. Teeter (2001). Effects of dietary L-carnitine (carniking) supplementation on overall performance and carcass characteristics of seven-week-old broiler chickens. Anim. Sci., 12:125-127.

Duncan, D.B. (1955). Multiple range and Multiple F tests. Biometrics, 11: 1-42.

Ellis, E.M.; J.E. Williams; E.T. Mallionson; G.H. Snoeyeribose and W.J. Martin (1976). Culture methods for the detection of animal salmonellosis and arizonosis. A manual of Amer. Assoc. Vet. Lab. Diag. Iowa State Univ. Press, Ames. U.S.A., 48-54.

El-Shafei, A.A.; M.M. Arafa; A.S. Abdelrahman and G.H. Elsakkar (2013). Physiological, biochemical and histopathological changes of ethylenediaminetetraacetic acid (EDTA) and vitamin $\mathrm{C}$ supplementation in broiler chicks diets. J. Amer. Sci., 9 (2): 316-333.

Fuller, R. (1989). Probiotics in man and animals. J. Appl. Bacteriol., 66: 365-378.

Geng A.; G. Yuming and Y. Jianmin (2004). Effects of dietary L-carnitine and coenzyme Q10 supplementation on performance and ascites mortality of broilers. Arch. Anim. Nutr., 58 (6): 473-482.

Geng A.; L. Baoming and G. Yuming (2007). Effects of dietary L-carnitine and coenzyme Q10 at different supplemental ages on growth performance and some immune response in ascites-susceptible broilers. Arch. Anim. Nutr., 61 (1): 50-60.

Gouda, H. (2002). Microbiological studies on some fish aquacultures in Egypt, B.Sc. Thesis Faculty of Agriculture. Cairo University, Egypt, 52-69.

Hedrick, H.; B.E. Aberle; J.C. Forrest; M.D. Judge and R.A. Merkel (1994). In Principles of Meat Science, Ch 3, pp. 55-78. Dubuque, Iowa, Kendall/ Hunt Publ.

Higgins, J.P.; S.E. Higgins; J.L. Vicente; A.D. Wolfenden; G. Tellez and B.M. Hargis (2007). Effect of probiotic treatment in broiler chicks on intestinal macrophage numbers and phagocytosis of Salmonella enteritidis by abdominal exudate cells. Poult. Sci., 86: 1662-1666. 


\section{Thabet et al.}

Hrnčár, C.; S. Verguliaková; P. Svorad; J. Weis; H. Arpášová; S. Mindek; M. Fik and J. Bujko (2015). Effect of L-carnitine supplementation on fattening and carcass parameters of broiler chickens. Acta. fytotechn. zootechn., 18 (1): 15-19.

Huang, H.K.; Y.J. Choi; R. Hude; J.W. Lee; B. Lee and V. Zhao (2004). Effects of Lactobacilli and an acidophilic fungus on the production performance and immune responses in broiler chickens. Poult. Sci., 83: 788-795.

Junqueira, I.C. J. Carnerior and J.A. Long (1971). Basic Histology. Chapter 1, 5th Ed., Editiora Guanabara Koogan S.A., Riode Janerio, Brazil.

Kabir, S.M., (2009). The role of probiotics in the poultry industry. Int. J. Mol. Sci., 10: 3531-3546.

Kaoud, H.A. (2010). Functional food supplementation and health of broilers. Nat. Sci., 8: 181-189.

Kauffmann, F. (1973). Serological diagnosis of salmonella species. Kauffmann white scheme, Copenhagen, Denmark.

Konca, Y.; F. Kirkpinar; S. Mert and S. Yurseven (2009). Effect of dietary ascorbic acid supplementation of growth performance, carcass, bone quality and blood parameters in broilers during natural summer temperature. Asia. J. Anim. Vet. Adv., 4 (3): 139-147.

Krieg, N.R. and J.G. Holt (1984). Bergey's Manual of Systemic Bacteriology, $8^{\text {th }}$ Ed. Williams and Wilkins, Baltimore, London, Vol. 1: 111-117.

Leibetseder, J. (1995). Studies on the effects of L-carnitine in poultry. Arch. Anim. Nutr., 48: 97-108.

Lettner, F.; W. Zollitsch and E. Halbamyer (1992). L-carnitine in broilers. Bodenkultur 43: 161-167.

Lien, T.F. and Y.M. Horng (2001). The effect of supplementary dietary L-carnitine on the growth performance, serum components, carcass traits and enzyme activities in relation to fatty acid $\beta$ oxidation of broiler chickens. Br. Poult. Sci., 42: 92-95.

Lohakare, J.D.; M.H. Ryu; T.W. Hahn; J.K. Lee and B.J. Chae (2005). Effects of supplemental ascorbic acid on the performance and immunity of commercial broilers. J. Appl. Poult. Res., 14: 10-19.

Mbajiorgu, C.A.; J.W. Ngambi and D. Norris (2007). Effect of time of initiation of feeding after hatching and influence of dietary ascorbic acid supplementation on productivity, mortality and carcass characteristics of Ross 308 broiler chickens in South Africa. Int. J. Poult. Sci., 6(8): 583-591.

McCann, M.E.E.; E. Newell; C. Preston and K. Forbes (2006). The use of mannan-oligosaccharides andor tannin in broiler diets. Int. J. Poult. Sci., 5(9): 873-879.

Mercuri, A.J. and N.A. Cox (1979). Coliforms and Enterobacteriaceae isolates from selected foods. J. Food Protect., 42 (9): 712-714.

Midilli, M.; M. Alp; N. Kocabağlı; Ö.H. Muğlalı; N. Turan; H. Yılmaz and S. Çakır (2008). Effects of dietary probiotic and prebiotic supplementation on growth performance and serum IgG concentration of broilers. South Afr. J. Anim. Sci., 38 (1): 21-27.

Montes, A.J. and D.G. Pugh (1993). The use of probiotics in food-animal practice. Veterinary Medicine, 88: 282-288.

Mountzouris, K.C.; P. Tsirtsikos; E. Kalamara; S. Nitsch; G. Schatzmayr and K. Fegeros (2007). Evaluation of the efficacy of a probiotic containing Lactobacillus, Bifidobacterium, Enterococcus, and Pediococcus strains in promoting broiler performance and modulating caecal microflora composition and metabolic activities 1 Poult. Sci., 86: 309-317.

NRC (1994). National Research Council. Composition of poultry feed stuffs. Nat. Acad. Sci. Washington, D.C.

Ogunwole, O.A.; Y.A.A. Oso; R.R. Omotoso; B.C. Majekodunmi; B.O. Ayinde and I. Oikeh (2013). Performance, carcass characteristics and meat physico-chemical properties of broiler chickens fed graded levels of supplemental ascorbic acid. Agric. Biol. J. N. Am., 4 (4): 485-495.

O’Keefe, T. (2005). Digestive aids: A brave new world ofnutrition. Poult. Int., 44 (7): 26-30.

Onu, P.N. (2009). Growth performance, carcass characteristics and economic benefits of supplemental ascorbic acid on broiler starters exposed to heat stress. J. Agric. Biol. Sci., 4 (5): 19-23. 


\section{Thabet et al.}

Oosterom, J., G.J.A. de Wilde; E. De Boer, L.H. De Blaauw and H. Karman (1983). Survival of Campylobacter jejuni during poultry processing and pig slaughtering. J. Food Prot., 46 (8): 702-706.

Panda, A.K.; S.V. Ramarao; M.V.L.N. Raju and S.R. Sharma (2006). Dietary supplementation of actobacillus sporogenes on performance and serum-biochemico-lipid profile of broiler chickens. J. Poult. Sci., 43: 235-240.

Rabie, M.H. and M. Szilagyi (1998). Effects of L-carnitine supplementation of diets differing in energy levels on performance, abdominal fat content, and yield and composition of edible meat of broilers. Br. J. Nutr., 80: 391-400.

Rabie, M.H.; M. Szilagyim; T. Gippertt; E. Votisky and D. Gerendai (1997). Influence of dietary Lcarnitine on performance and carcass quality of broiler chickens. Acta Biol. Hung., 48:241-252.

Rezaei, M.; A. Attar; A. Ghodratnama and H. Kermanshahi (2007). Study the effects of different levels of fat and L-carnitine on performance, carcass characteristics and serum composition of broiler chicks. Pakistan J. Biol. Sci., 10 (12): 1970-1976.

Ryu, Y.C.; M.S. Rhee and B.C. Kim (2004). Estimation of correlation coefficients between histological parameters and carcass traits of pig longissimus dorsi muscle. Asian-Aust. J. Anim. Sci., 17: 428-433.

Sabah-Elkheir, M.K.; M.M.M. Ahmed and S.M. Abdelgadir (2008). Effect of feed restriction and ascorbic acid supplementation on performance of broiler chicks reared under heat stress. Res. J. Anim. Vet. Sci., 3: 1-8.

Sahin, K.; N. Sahin and O. Kucuk (2003). Effects of chromium, and ascorbic acid supplementation on growth, carcass traits, serum metabolites, and antioxidant status of broiler chickens reared at a high ambient temperature $\left(32^{\circ} \mathrm{C}\right)$. Nutr. Res., $23: 225-238$.

Santine, E; A. Maiorka; M. Macari; M. Grecco; T.M. Okada and A.M. Myasaka (2001). Performance and intestinal mucosa development of broiler chickens fed diets containing Saccahromyces cerevisiae cell wall. J. Appl. Poult. Res., 10: 236-244.

SAS (1998). Statistical Analysis System, SAS User's Guide: Statistics Ver. 6.04, $4^{\text {th }}$ ed. SAS Institute. Inc., Cary, NC. USA.

Sosnowka-Czajka, E.; I. Skomorucha and E. Herbut (2005). Effect of dietary vitamin supplements on productivity and physiological parameters of broiler chickens exposed to elevated ambient temperature. International Society for Animal Hygiene, ISAH Vol 2. pp. 111-114. Warsaw, Poland.

Swain, B.K.; P.K. Naik; E.B. Chakurkar and N.P. Singh (2012). Effect of Combined Supplementation of probiotic and yeast on growth, carcass characteristics and economics of production in broiler chickens. Anim. Nutr. Feed Technol., 12: 103-110.

Tůmová, E. and A. Teimouri (2009). Chicken Muscle fibers characteristics and meat quality: A Review. Scientia Agriculturae Bohemica, 40 (4): 253-258.

USDA-FSIS “United State Department of Agriculture, Food Safety Inspection Service” (1989). Method for the Isolation and Identification of Listeria monocytogenes from meat and poultry products. Laboratory communication NO. 57 U.S. department of agriculture, Washington, D.C.

Villar-Patiño, G.; A. Díaz-Cruz; E. Avila-González; R. Guinzberg; J.L. Pablos and E. Piña (2002). Effects of dietary supplementation with vitamin $\mathrm{C}$ or vitamin $\mathrm{E}$ on cardiac lipid peroxidation and growth performance in broilers at risk of developing ascites syndrome. Am. J. Vet. Res., 63 (5): 673-682.

Wang, J.; R. Du; J. Qin; S. Wang; W. Wang; H. Li and Q. Pang (2003). Effect of yeast chromium and Lcarnitine on lipid metabolism of broiler chickens. Asian-Aust. J. Anim. Sci., 16 (12): 1809-1815.

Xu, Z.R.; M.Q. Wang; H.X. Mao; X.A. Zhan and C.H. Hu (2003). Effects of L-carnitine on growth performance, carcass compositon and metabolism of lipids in male broilers. Poult. Sci., 82: 408-413. 

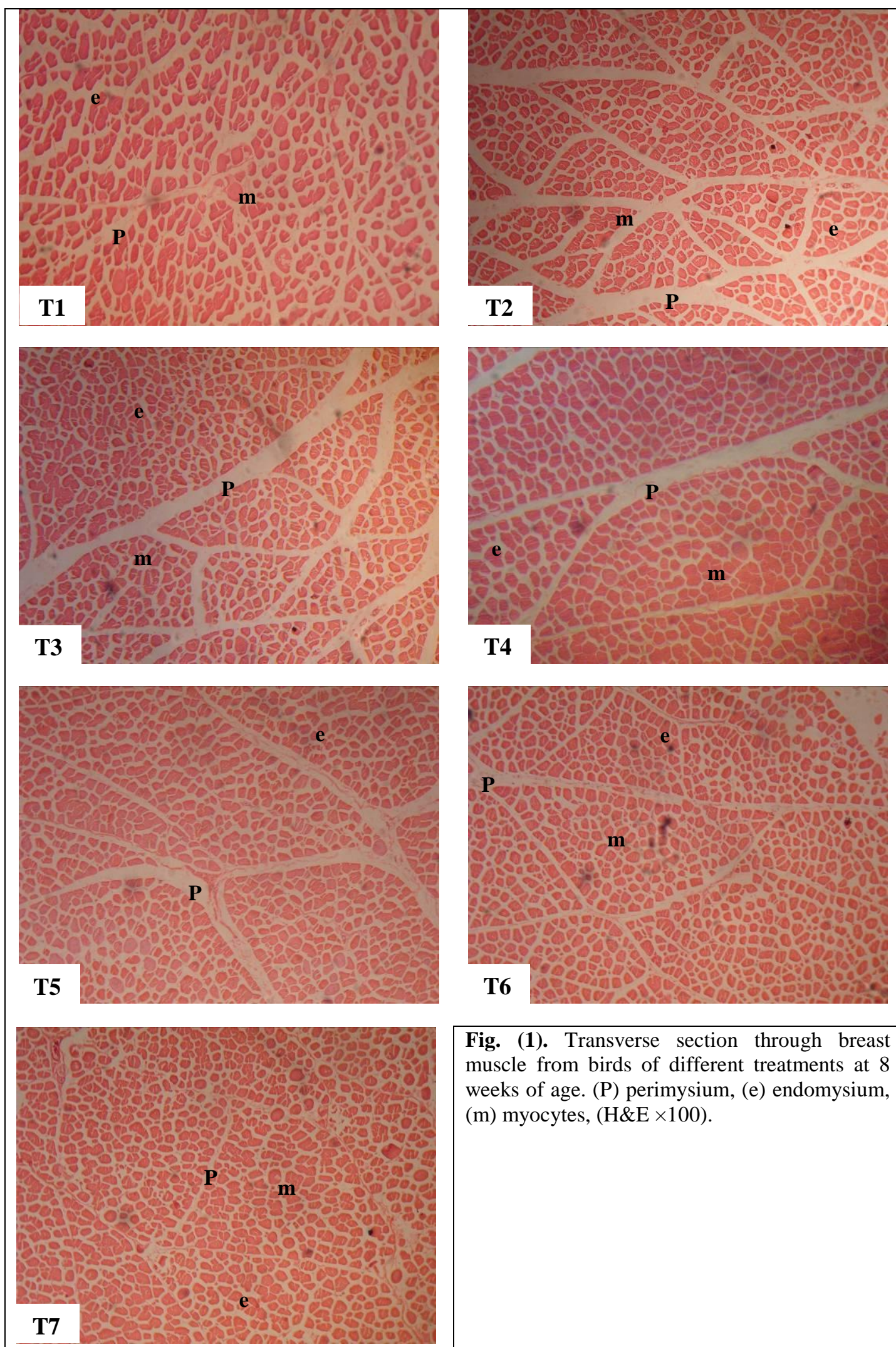

Fig. (1). Transverse section through breast muscle from birds of different treatments at 8 weeks of age. (P) perimysium, (e) endomysium, (m) myocytes, $(\mathrm{H} \& \mathrm{E} \times 100)$.

T1: Basal diet, T2: Basal diet + Ascorbic acid $500 \mathrm{mg} / \mathrm{Kg}$, T3: Basal diet + Ascorbic acid $1000 \mathrm{mg} / \mathrm{Kg}, \mathrm{T4}$ : Basal diet + L-Carnitine $75 \mathrm{mg} / \mathrm{Kg}$, T5: Basal diet + L-Carnitine $150 \mathrm{mg} / \mathrm{Kg}$, T6: Basal diet + Probax $0.5 \mathrm{~g} /$ $\mathrm{Kg}$, T7: Basal diet + Probax $1.0 \mathrm{~g} / \mathrm{Kg}$. 

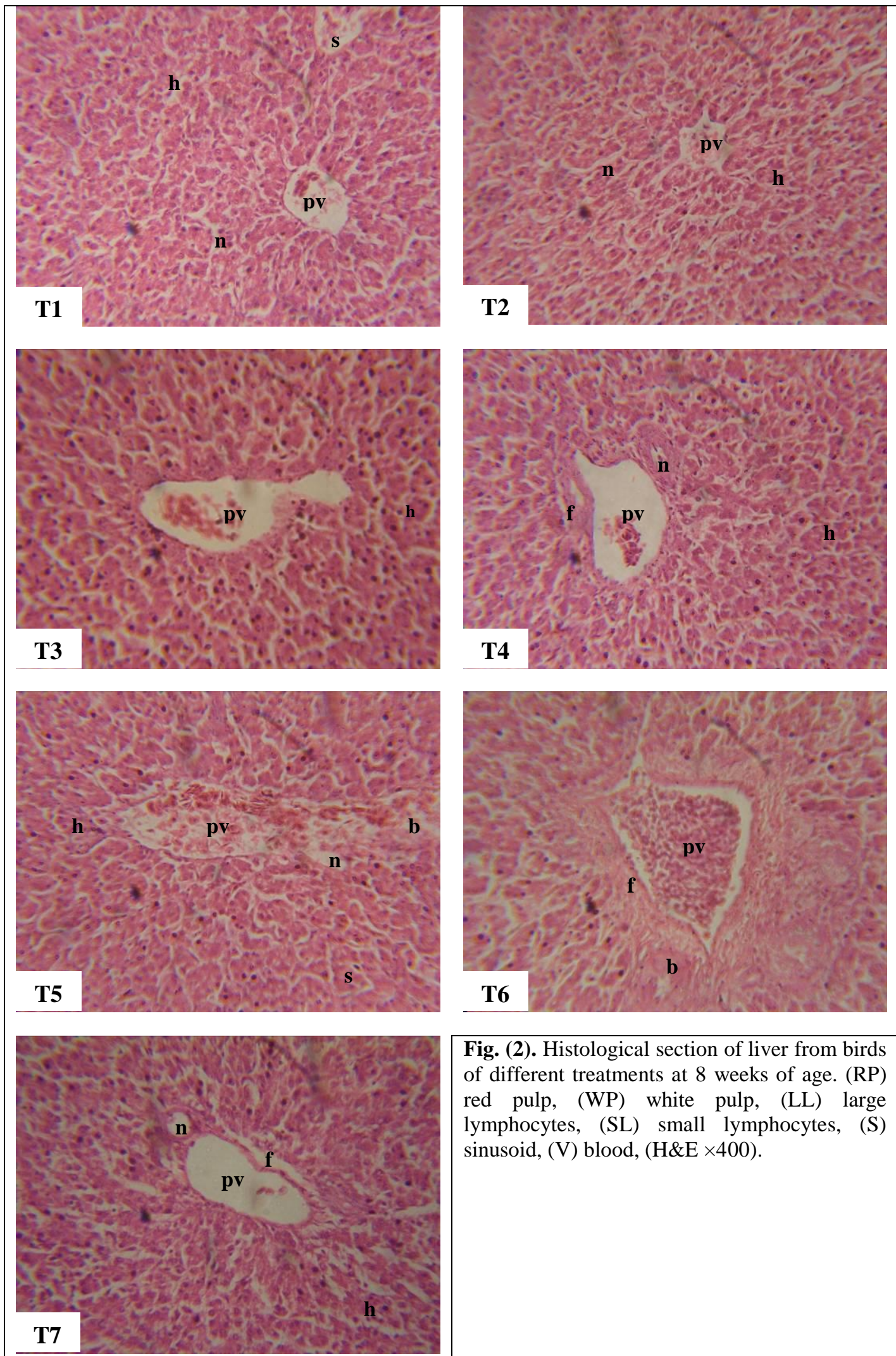

Fig. (2). Histological section of liver from birds of different treatments at 8 weeks of age. (RP) red pulp, (WP) white pulp, (LL) large lymphocytes, (SL) small lymphocytes, (S) sinusoid, (V) blood, (H\&E $\times 400)$.

T1: Basal diet, T2: Basal diet + Ascorbic acid $500 \mathrm{mg} / \mathrm{Kg}$, T3: Basal diet + Ascorbic acid $1000 \mathrm{mg} / \mathrm{Kg}, \mathrm{T4}$ : Basal diet + L-Carnitine $75 \mathrm{mg} / \mathrm{Kg}$, T5: Basal diet + L-Carnitine $150 \mathrm{mg} / \mathrm{Kg}$, T6: Basal diet + Probax $0.5 \mathrm{~g} /$ 
Thabet et al.

Kg, T7: Basal diet + Probax $1.0 \mathrm{~g} / \mathrm{Kg}$.
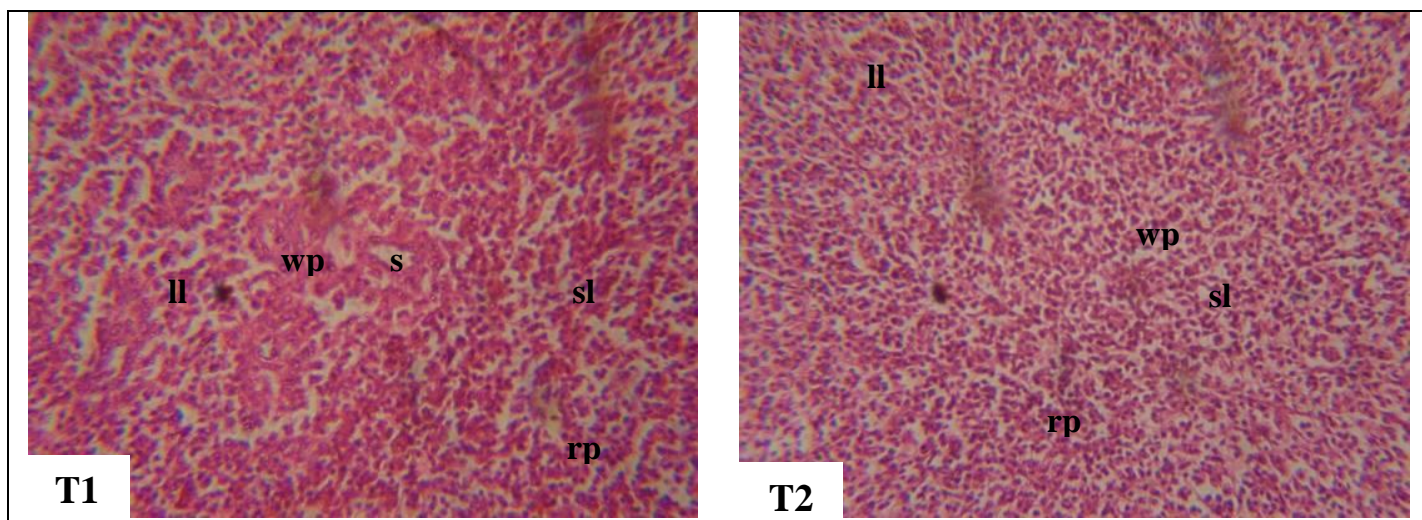

T2
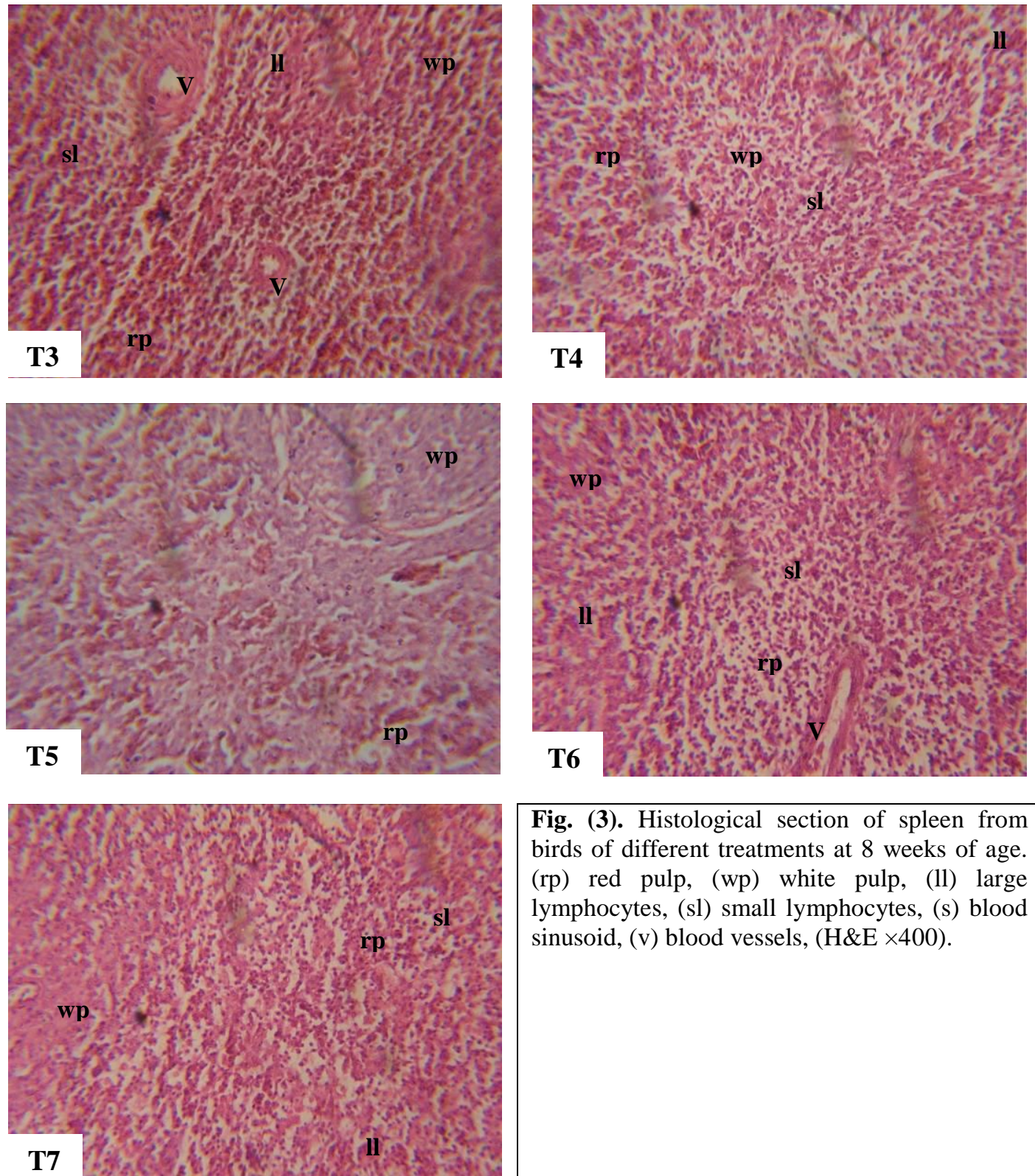

Fig. (3). Histological section of spleen from birds of different treatments at 8 weeks of age. (rp) red pulp, (wp) white pulp, (1l) large lymphocytes, (sl) small lymphocytes, (s) blood sinusoid, (v) blood vessels, $(\mathrm{H} \& \mathrm{E} \times 400)$.

T1: Basal diet, T2: Basal diet + Ascorbic acid $500 \mathrm{mg} / \mathrm{Kg}$, T3: Basal diet + Ascorbic acid $1000 \mathrm{mg} / \mathrm{Kg}$, T4: Basal diet + L-Carnitine $75 \mathrm{mg} / \mathrm{Kg}$, T5: Basal diet + L-Carnitine $150 \mathrm{mg} / \mathrm{Kg}$, T6: Basal diet + Probax $0.5 \mathrm{~g} / \mathrm{Kg}$, T7: Basal diet + Probax $1.0 \mathrm{~g} / \mathrm{Kg}$. 
تأثير إستخدام دـكارنيتين، حمض الأسكوربيك والبروبيوتيك على الآداء الإتتاجى، الحمل الميكروبي والتركيب النسيجى فى دجاج التسمين المستنبط محليا

\author{
هانى على ثابت1، محمد إبراهيم شراب1، مروان عبدالعزيز محمود عبدالعزيز و و أحمد فريد عبدالسلام²

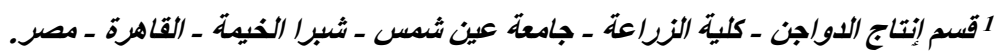

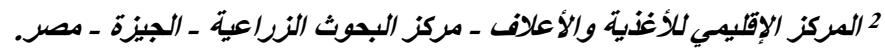

فى تجربة أجريت لدراسة تأثير إستخدام لــكارنيتين، حمض الأسكوربيك والبربيوتيك على الآداء الإنتاجي، وخصائص الذبيحة

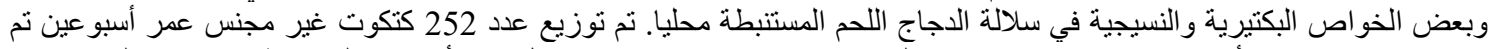

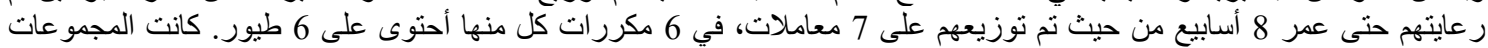

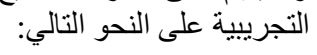

T: T1 : مجمو عة كونترول تم تغذيتها على العليقة القاعدية.

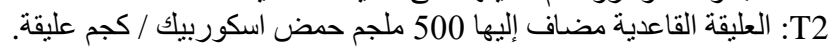

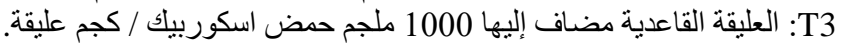
T4 :T4: العليقة القاعدية مضاف إليها 75 ملجم لــكارنيتين / كجم عليقة.

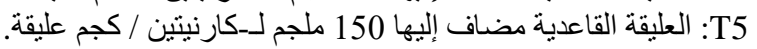

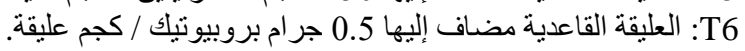

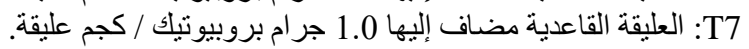
النتائج المتحصل عليها يمكن تلخيصها على النحو النالي:

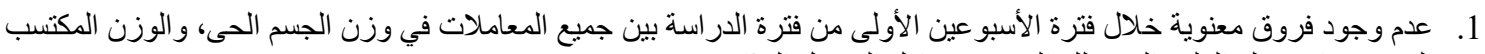

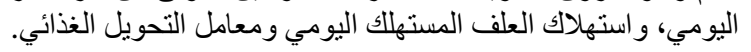

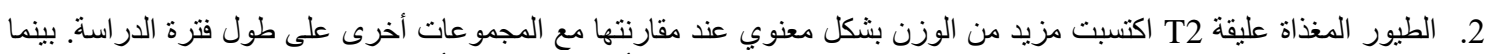

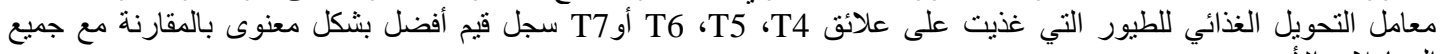
المعاملات الأخري.

3. إددادت النسبة المئوية للذبيحة مع جميع المعاملات التجريبية بشكل معنوى مقارنة مع مجموعة الكونترول. بينما الطيور المغذاة علائق T3 أو T5 سجلت أقل معدل من دهن البطن بشكل معنوى بالمقارنة مع جميع المعاملات.

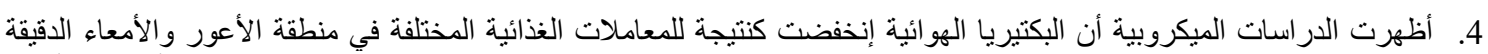

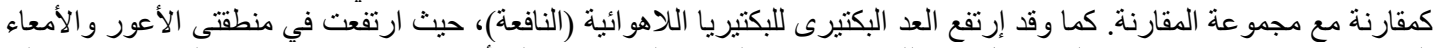

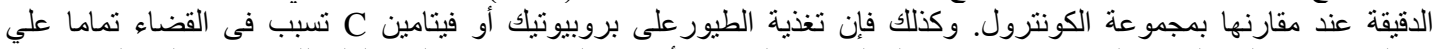

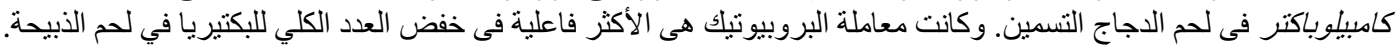

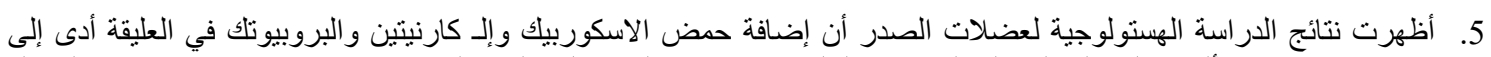

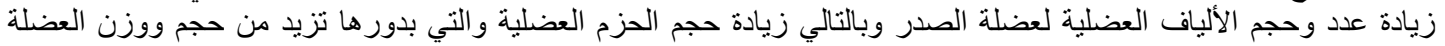

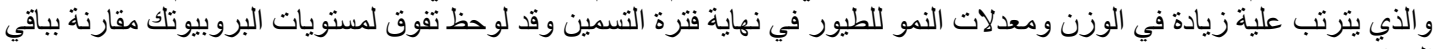
المعاملات.

6. التركيب الهستولوجي للكبد كان طبيعياً في كل المعاملات ولم تظهر أى إختلافات جوهرية أو وجود علامات مرضية ناتجة عن المعاملات.

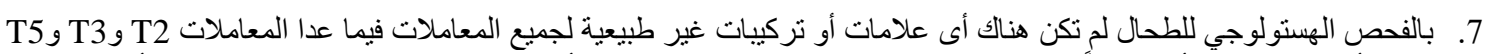

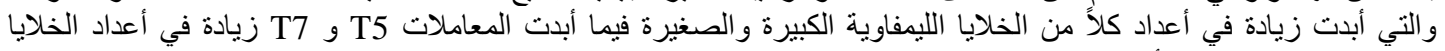
الليففاوية الكبيرة مقارنة بأعداد الخلايا الليمفاوية الصغيرة.

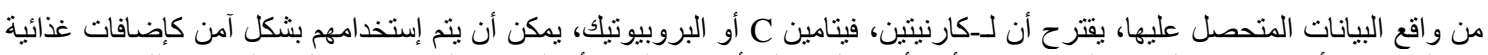
لتحسين الأداء الإنتاجى لطيور التسمين دون أي تأثئير سلبي على أعضاء الجسم أو الهجنمع البكتيري في القناة الهضمية للطيور. 